\title{
Hazard Analysis for Phytophthora Species in Container Nurseries: Three Case Studies
}

\author{
Jennifer L. Parke ${ }^{2}$, Neelam R. Redekar, Joyce L. Eberhart, \\ and Fumiaki Funahashi ${ }^{1}$
}

ADDITIONAL INDEX WORDs. disease management, irrigation water, oomycetes, production practices, Phytopythium, Pythium, systems approach

Summary. Phytophthora species cause crop losses and reduce the quality of greenhouse and nursery plants. Phytophthora species can also be moved long distances by the plant trade, potentially spreading diseases to new hosts and habitats. Phytosanitary approaches based on quarantines and endpoint inspections have reduced, but not eliminated, the spread of Phytophthora species from nurseries. It is therefore important for plant production facilities to identify potential sources of contamination and to take corrective measures to prevent disease. We applied a systems approach to identify sources of contamination in three container nurseries in Oregon, California, and South Carolina. Surface water sources and recaptured runoff water were contaminated with plant pathogenic species at all three nurseries, but one nursery implemented an effective disinfestation treatment for recycled irrigation water. Other sources of contamination included cull piles and compost that were incorporated into potting media, infested soil and gravel beds, used containers, and plant returns. Management recommendations include preventing contact between containers and contaminated ground, improving drainage, pasteurizing potting media ingredients, steaming used containers, and quarantine and testing of incoming plants for Phytophthora species. These case studies illustrate how recycled irrigation water can contribute to the spread of waterborne pathogens and highlight the need to implement nursery management practices to reduce disease risk.

$\mathrm{D}$ iseases caused by Phytophthora species are among the most damaging to greenhouse and nursery-grown horticultural crops (Jones and Benson, 2001; U.S. Department of Agriculture, 2009). These

Received for publication 4 Feb. 2019. Accepted for publication 12 Apr. 2019

Published online 5 August 2019.

Department of Crop and Soil Science, Oregon State University, Corvallis, OR 97331

Our project was funded by the U.S. Department of Agriculture National Institute of Food and Agriculture Specialty Crop Research Initiative (USDANIFA-SCRI) program (grant 2014-51181-22372).

Mention of a trademark, proprietary product, or vendor does not constitute a guarantee or warranty of the product by Oregon State University and does not imply its approval to the exclusion of other products or vendors that also may be suitable. We are grateful to the three anonymous nurseries for their cooperation during the course of this study.

This paper is based on information presented during the Clean Wate ${ }^{3}$ program sessions, held as part of the ASHS Annual Conference, 30 July-3 Aug. 2018 in Washington, DC

${ }^{1}$ Current address: Copine International Agriculture and Environment LLC, Gifu, Japan.

${ }^{2}$ Corresponding author. E-mail: Jennifer.Parke@ oregonstate.edu.

This is an open access article distributed under the $\mathrm{CC}$ BY-NC-ND license (https://creativecommons.org/ licenses/by-nc-nd/4.0/).

https://doi.org/10.21273/HORTTECH04304-19 pathogens cause damping-off diseases, root rot, stem cankers, shoot dieback and foliar blight of annuals, herbaceous perennials, and woody plants. While Phytophthora includes soilborne and aerial species (Garbelotto et al., 2018), they are water molds, meaning they require water to complete their life cycles. Sporangia are formed during moist conditions, releasing zoospores that swim through water to infect plant roots, stems, and leaves. Phytophthora and other plant pathogenic oomycetes including Phytopythium and Pythium are common contaminants of greenhouse and nursery irrigation systems (Ivors and Moorman, 2017).

In addition to causing crop losses in the nursery and reducing plant quality, Phytophthora species can also be spread long distances by the nursery trade, and some pose risks for forests and other natural vegetation. For example, the sudden oak death pathogen Phytophthora ramorum was likely introduced to North America on nursery plants in the mid-1990s (Goss et al., 2009). In California and Oregon, sudden oak death has killed $\approx 35$ million forest trees (Cobb, 2018). Despite quarantines imposed on nurseries in California, Oregon, and Washington, P. ramorum was dispersed across the country with the nursery trade (Goss et al., 2009). Other examples of Phytophthora species spread to wildlands by the plant trade include $P$. lateralis, which causes port-orford-cedar root disease (Hansen et al., 2000), and $P$. tentaculata, a pathogen that spread from native plant nurseries to restoration sites (Garbelotto et al., 2018; RooneyLatham et al., 2015; Sims and Garbelotto, 2018).

Nursery plant distribution systems are effective at moving pathogens (Jung et al., 2018; Liebhold et al., 2012). Infected plants may not show symptoms (Parke and Lewis, 2007). In addition, some of the most widely used oomycetespecific pesticides, such as mefenoxem and fosetyl-Al, are fungistatic rather than fungicidal. Application of these materials can delay the development of symptoms and prevent pathogen detection until after plants are shipped. Resistance to mefenoxam has also developed in many nurseries (Olson et al., 2013). Once nursery beds are infested, it is difficult to eradicate Phytophthora species. Soil steaming (Schweigkofler et al., 2014) and soil solarization (Funahashi and Parke, 2016) are effective but require large energy inputs or summer fallow periods, respectively. It is far less expensive to implement protective measures preventing disease than it is to eradicate Phytophthora species once they have established.

\begin{tabular}{llll}
\hline $\begin{array}{l}\text { Units } \\
\text { To convert U.S. to SI, } \\
\text { multiply by }\end{array}$ & U.S. unit & SI unit & $\begin{array}{l}\text { To convert SI to U.S., } \\
\text { multiply by }\end{array}$ \\
\hline 0.4047 & acre $(\mathrm{s})$ & $\mathrm{ha}$ & $2.471 \mathrm{l}$ \\
29,574 & $\mathrm{fl} \mathrm{oz}$ & $\mu \mathrm{L}$ & $3.3814 \times 10^{-5}$ \\
3.7854 & gal & $\mathrm{L}$ & 0.2642 \\
2.54 & inch $(\mathrm{es})$ & $\mathrm{cm}$ & 0.3937 \\
16.3871 & inch $^{3}$ & $\mathrm{~cm}^{3}$ & 0.0610 \\
1 & micron $(\mathrm{s})$ & $\mu \mathrm{m}$ & 1 \\
1 & ppm & $\mathrm{ng} \cdot \mu \mathrm{L}^{-1}$ & 1 \\
$\left({ }^{\circ} \mathrm{F}-32\right) \div 1.8$ & ${ }^{\circ} \mathrm{F}$ & ${ }^{\circ} \mathrm{C}$ & $\left({ }^{\circ} \mathrm{C} \times 1.8\right)+32$ \\
& & &
\end{tabular}


For several years we have applied a systems approach to identify sources of pathogen contamination within nurseries (Parke and Grünwald, 2012). The system is a modification of the hazard analysis of critical control points (HACCP) approach designed to ensure food safety in food processing facilities. Critical control points are defined as the best stages in a production process at which significant hazards of contamination can be prevented or reduced. In a nursery, critical control points for contamination by plant pathogens commonly include plants brought in from other production facilities, potting media or ingredients, cull piles that are used for making potting media, recycled containers, the soil or gravel under the containers, and untreated irrigation water. Once the source(s) of contamination is known, nursery growers can eliminate or reduce the risk of disease by implementing a management strategy that targets the contamination source (Junker et al., 2016; Parke and Grünwald, 2012; Parke et al., 2014).

In this article, we describe how we conducted a hazard analysis of three container nurseries to determine sources of contamination for Phytophthora species and show how our findings can inform management strategies to eliminate or reduce the sources of contamination.

\section{Material and methods}

Sample Collection, leaf BAITING, AND FILTRATION. Hazard analyses of critical control points were performed at three container nurseries located in Oregon (Nursery A), California (Nursery B), and South Carolina (Nursery C) in Oct. 2017, Dec. 2017, and June 2016, respectively. Each nursery was surveyed to locate areas with high disease risks to allow for thorough sampling of these areas and surroundings. The types of samples collected from these nurseries included 1) diseased plants showing symptoms such as dieback, root rot, shoot blight, leaf lesions, defoliation (Fig. 1A-E); 2) soil, gravel, and leaf debris from underneath the pots from a symptomatic area (Fig. 2AD); 3) media components such as potting mix and compost (Fig. 3B); 4) scrapings from used containers to be recycled (Fig. 3C); 5 ) plant debris
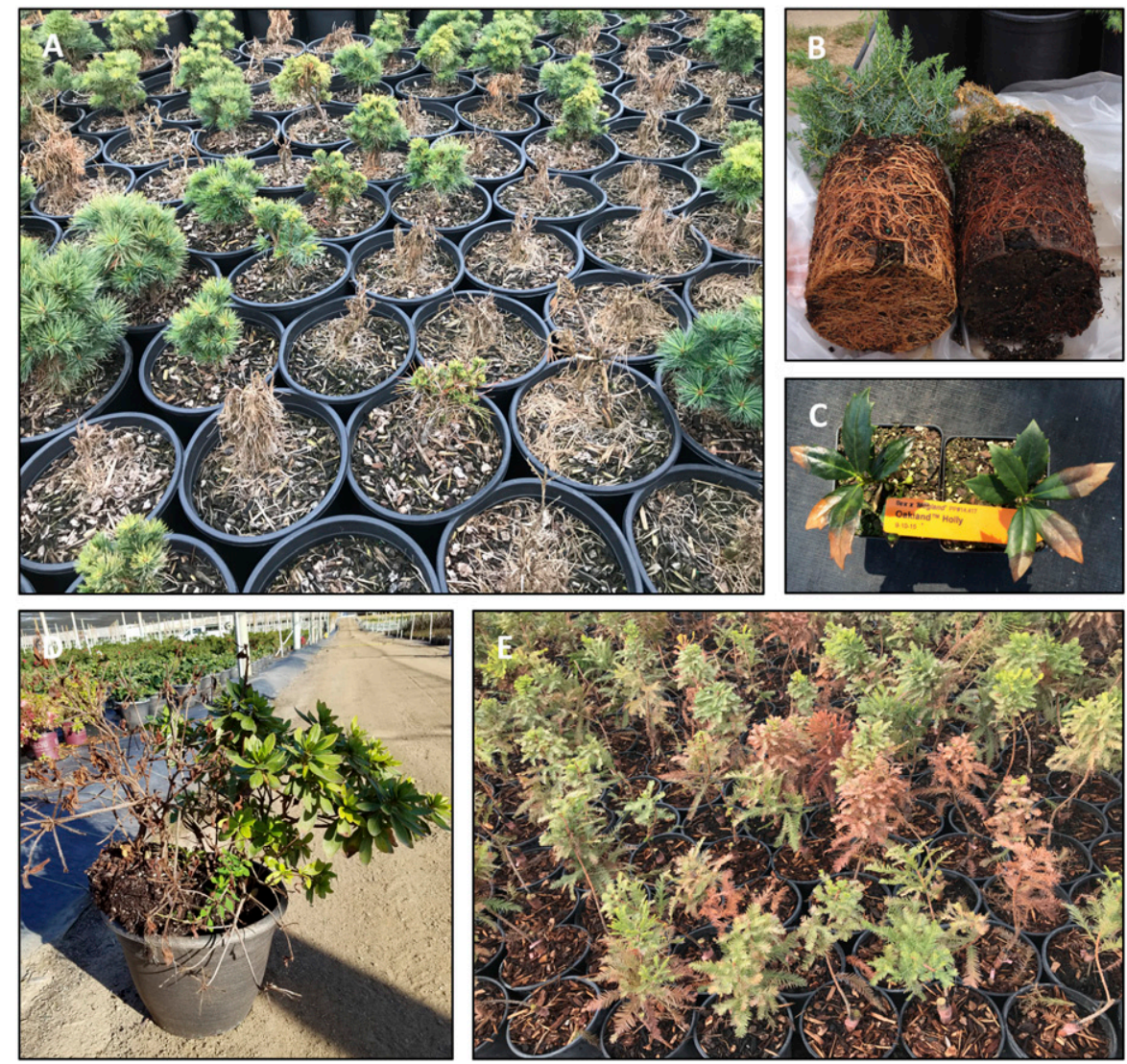

Fig. 1. Diseased plants found at container nurseries in Oregon, California, or South Carolina: (A) pine (Pinus sp.) mortality, (B) juniper (Juniperus sp.) root rot (right) compared with healthy plant (left), (C) foliar blight of holly (Ilex sp.), (D) azalea (Rbododendron sp.) dieback, and (E) bald cypress (Taxodium distichum) mortality.

in cull piles (Fig. 3E); and 6) irrigation water from main sources, retention reservoirs, and runoff channels (Figs. 3A and 4A). At least 50 samples were collected in each nursery. We used a combination of enzyme-linked immunosorbent assay-based methods, culture-based methods, and DNA sequencing approaches to detect and identify Phytophthora species.

Plants exhibiting Phytophthoralike symptoms on roots or foliage were tested with Phytophthora on-site detection kits (Fig. 4C and D), and if positive, directly plated on Phytophthora-selective media (Parke et al., 2014) (Fig. 4E). For Nursery A and B, we used the Phytophthora Rapid test kit (Pocket Diagnostic; Abingdon Health, Sand Hutton, UK); for Nursery C we used the ImmunoStrip test (Agdia, Elkhart, IN). DNA from pure-isolate cultures was amplified using internal transcribed spacer primers ITS4 and ITSDC6 (details later in the article) and the nucleotide sequence of the polymerase chain reaction (PCR) product was determined with the Sanger sequencing method to identify pathogen species.

All sample types (including diseased plants) were baited using pesticide-free leaves of 'Grandiflorum' catawba rhododendron (Rhododendron catawbiense) grown in the Oregon State University research greenhouses (Fig. 4F). For diseased plants, either pour-through water [collected by pouring tap water into the pot and collecting the leachate (Swiecki et al., 2018)] or the root balls placed in a plastic bag and flooded with deionized water (Fig. $4 \mathrm{G}$ ) were baited. For other sample types such as soil, gravel, scrapings of used containers, media components, and plant debris, $\approx 200 \mathrm{~cm}^{3}$ of material was placed in 1 -gal plastic bags. Deionized water (1 L) was added to these bags for baiting at room temperature (19 to $21^{\circ} \mathrm{C}$ ). Irrigation water (1 L) was directly used for 


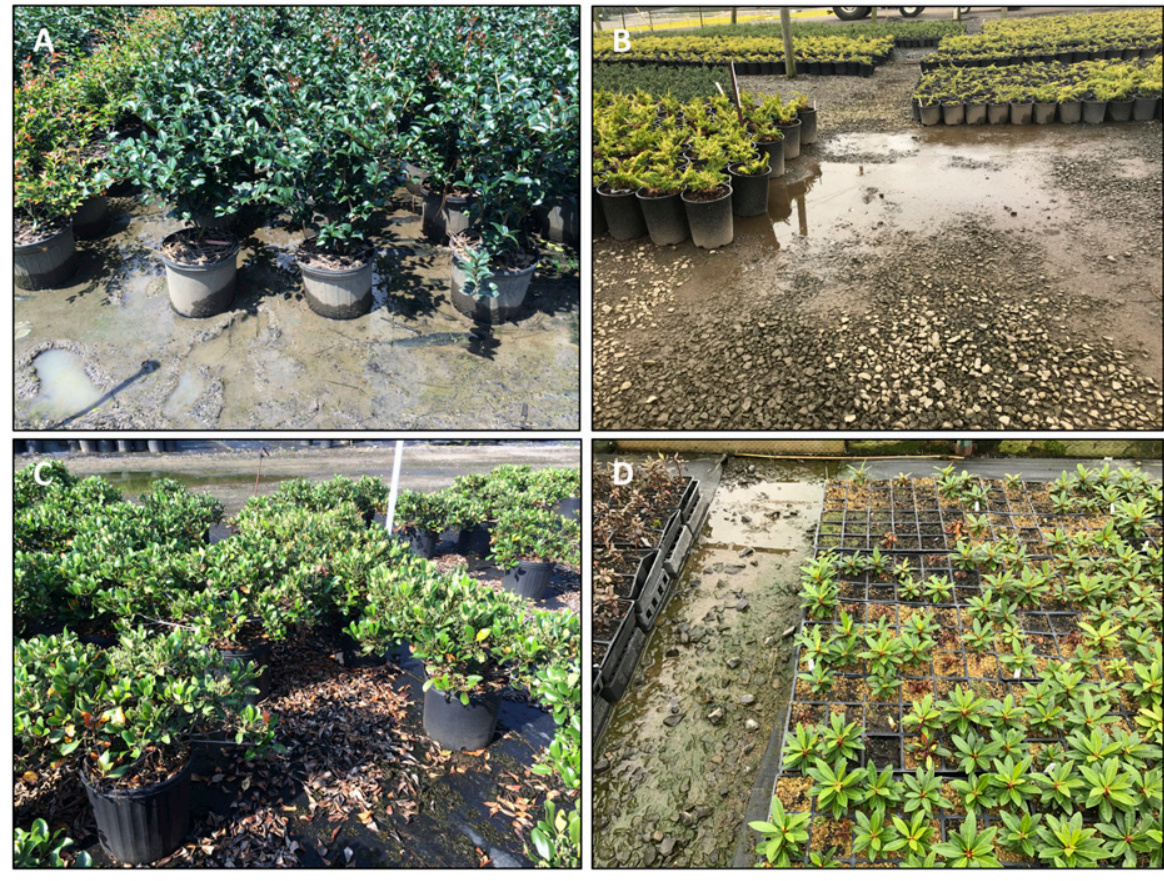

Fig. 2. Contamination hazards associated with container nursery management practices: (A) pots on poorly drained surface, $(B)$ puddling of runoff water in the growing beds, (C) accumulation of plant leaf debris on top of weed cloth, and (D) pattern of plant mortality may reflect splashing from puddle.
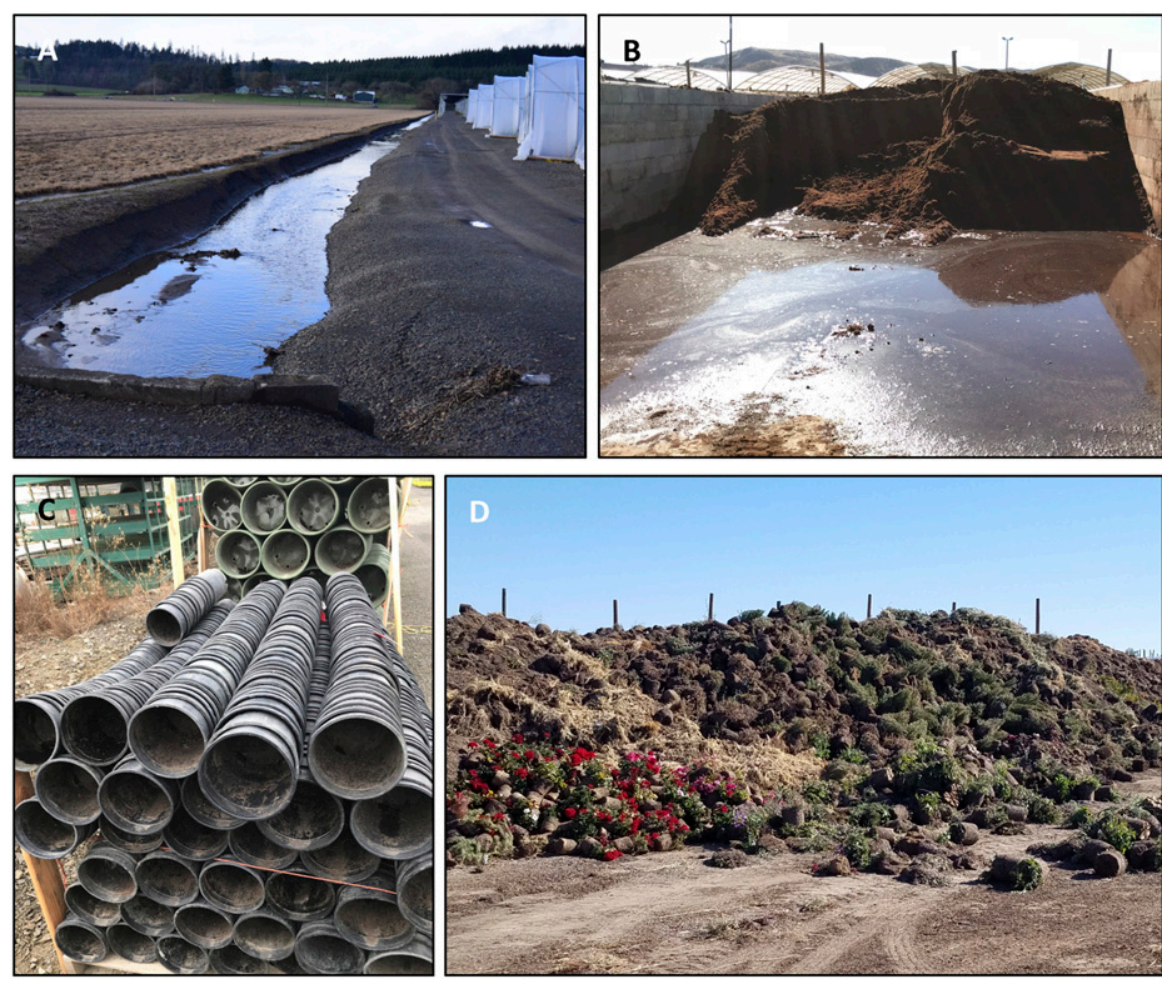

Fig. 3. Contamination hazards involved in container nursery plant production processes: (A) untreated recycled water, $(B)$ potting mix with standing water, $(C)$ reused containers, and (D) diseased plants added to cull pile.

baiting. For baiting, one-half 'Grandiflorum' catawba rhododendron leaf was floated in a sample bag for $3 \mathrm{~d}$, followed by incubation for $7 \mathrm{~d}$ more in damp paper towels. If lesions formed, up to 10 leaf disks $(6 \mathrm{~mm}$ diameter) of lesioned tissue were removed with a hole punch and stored in bags with silica gel (Ockels et al., 2007) for future DNA extraction and identification of all Phytophthora species present through Illumina MiSeq (Illumina, San Diego, CA) sequencing. Illumina MiSeq is a high-throughput sequencing platform that allows for identification of individual species from a mixed pool of DNA in environmental samples.

An additional $1 \mathrm{~L}$ of irrigation water was filtered through $5-\mu \mathrm{m}$ mixed cellulose ester membrane filters (catalogue no. SSWP04700; EMD Millipore, Billerica, MA) (Fig. 4B) to detect species that could not be recovered by baiting or culturing; filters were stored at $-20^{\circ} \mathrm{C}$ in tubes containing $950 \mu \mathrm{L}$ cetyl trimethyl ammonium bromide $(\mathrm{CTAB})$ buffer with polyvinyl pyrrolidone (PVP) before DNA extraction.

DNA EXTRACTION AND ILlumina MiSeQ SEQUENCING. DNA was extracted from filters using a modified chloroform/phenol extraction method (Burke et al., 2006), and leaf baits using the Synergy 2.0 Plant DNA Extraction Kit (OPS Diagnostics, Lebanon, NJ). The extracted DNA was diluted with Tris-EDTA buffer when necessary to $25 \mathrm{ng} \cdot \mu \mathrm{L}^{-1}$ and stored at $-20^{\circ} \mathrm{C}$. For pure-isolate cultures, DNA was extracted from hyphae grown on Phytophthoraselective media plates using ExtractN-Amp Plant PCR Kit (Sigma-Aldrich, St. Louis, MO). DNA was amplified with oomycete-specific primers for Sanger or Illumina MiSeq sequencing that allowed us to detect Phytophthora species as well as species of Phytopythium and Pythium.

For Sanger sequencing, the internal transcribed spacer 1 (ITS1) region ( $>900 \mathrm{bp}$ ) was amplified from the DNA using ITSDC6 (5' -GAGGGACTTTTGGGTAATCA-3' ${ }^{\prime}$ and ITS4 (5'-TCCTCCGCTTATTGATATGC- $3^{\prime}$ ) primers (White et al., 1990). PCR was performed with Phusion High-Fidelity PCR Master Mix with HF Buffer (New England BioLabs, Ipswich, MA). The reaction was carried out as follows: initial denaturation at $98^{\circ} \mathrm{C}$ for $30 \mathrm{~s}, 35$ cycles of denaturation at $98{ }^{\circ} \mathrm{C}$ for $10 \mathrm{~s}$, annealing at $60{ }^{\circ} \mathrm{C}$ for $15 \mathrm{~s}$, and extension at $72{ }^{\circ} \mathrm{C}$ for $20 \mathrm{~s}$, followed by a final extension at $72^{\circ} \mathrm{C}$ for $5 \mathrm{~min}$. PCR products were visualized on a 2.5\% agarose gel to confirm positive PCR amplification. Amplified PCR 

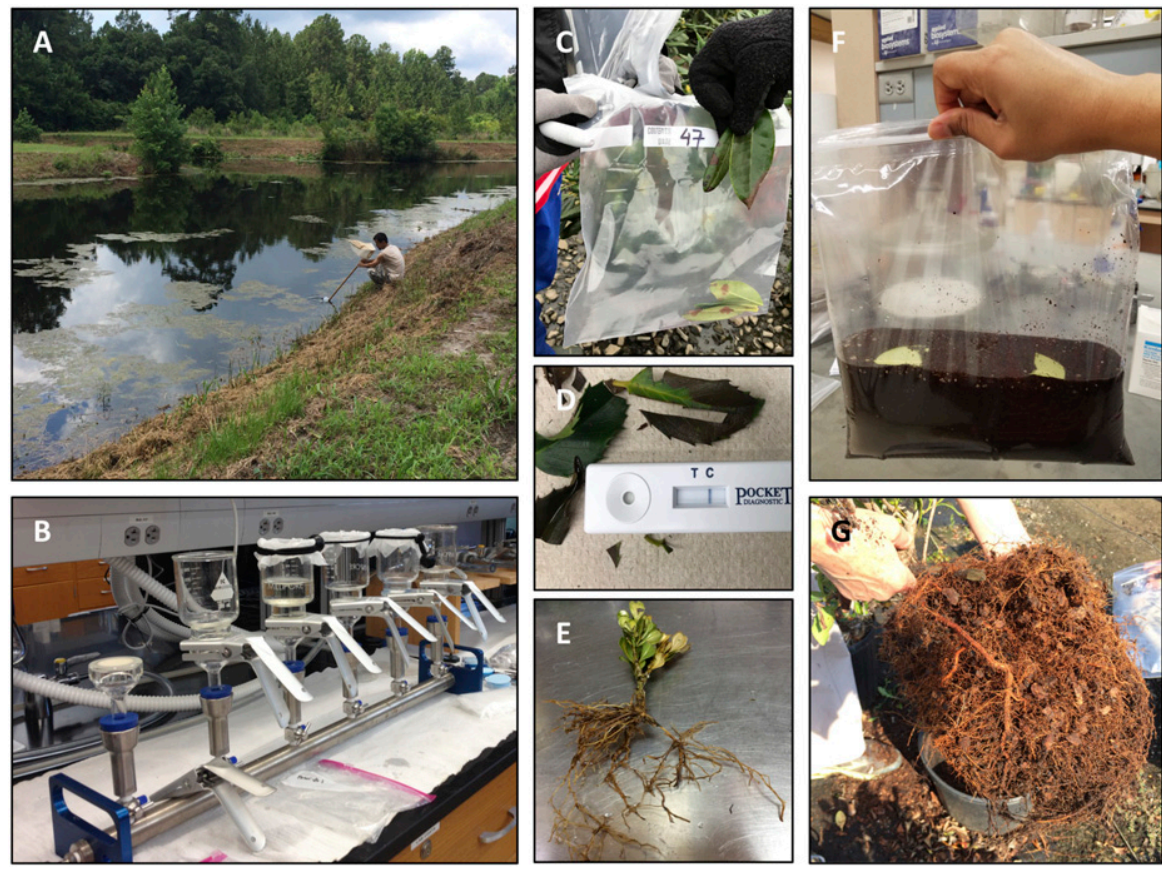

Fig. 4. Hazard analysis for Phytophthora species in container nurseries: (A) water being collected from the main source of irrigation water, $(B)$ filtration apparatus used to filter irrigation water samples, (C) rhododendron plant showing leaf blight symptoms, (D) rhododendron leaf lesions tested with Phytophthora Rapid test kit (Pocket Diagnostic; Abingdon Health, Sand Hutton, UK; test was positive for Phytophthora), (E) cleaned boxwood roots before plating on Phytophthoraselective media, $(\mathrm{F})$ baiting of potting $\mathrm{mix}$ with two half leaves of fungicide-free rhododendron, and (G) sampling of root ball for baiting.

products were cleaned with ExoSAPIT PCR Product Cleanup Reagent (Thermo Fisher Scientific, Waltham, MA). The cleaned PCR products were quantified, diluted to the required specifications, and submitted for Sanger sequencing, along with $12 \mathrm{pM}$ of either ITS4 or ITS6 (5'-GAAGGTGAAGTCGTAACAAGG-3') as the sequencing primer. Sanger sequencing was performed at the Center for Genomic Research and Biocomputing (CGRB) at Oregon State University.

For Illumina MiSeq sequencing, the ITSI region was amplified using modified ITS6 (5'-GAAGGTGAAGTCGTAACAAGG-3') and ITS7 (5' -AGCGTTCTTCATCGATGTGC-3') primers. The Nextera Universal adapter sequence $\left(5^{\prime}\right.$-TCGTCGGCAGCGTCAGATGTGTATAAGAGACAG-3') (Nextera DNA Library Preparation kit, Illumina) was incorporated at the $5^{\prime}$ ends of both primers. Up to $50 \mathrm{ng}$ of template DNA was used for the PCR reaction. The PCR master mix consisted of $1 \times$ reaction buffer, $800 \mu \mathrm{M}$ dNTP, $3.5 \mathrm{mM} \mathrm{MgCl}_{2}, 0.4 \mu \mathrm{M}$ of each primer, and Platinum Taq DNA polymerase (Thermo Fisher Scientific) enzyme in $25 \mu \mathrm{L}$ total PCR reaction volume. The reaction was carried out as follows: initial denaturation at $94{ }^{\circ} \mathrm{C}$ for 2 min, 35 cycles of denaturation at $94{ }^{\circ} \mathrm{C}$ for $45 \mathrm{~s}$, annealing at $60{ }^{\circ} \mathrm{C}$ for $30 \mathrm{~s}$, and extension at $72{ }^{\circ} \mathrm{C}$ for $1 \mathrm{~min}$, followed by a final extension at $72{ }^{\circ} \mathrm{C}$ for $10 \mathrm{~min}$. PCR products were sent to CGRB for dual-indexing with barcodes from the Nextera Index Kit (Illumina) and library preparation for high-throughput 250 to 300 paired-end run Illumina MiSeq sequencing.

Sequencing data analyses. All the sequencing data generated for the three nurseries were analyzed separately. Sanger sequencing data were trimmed at ends to remove noisy nucleotide bases, and every sequence was separately queried against the ITS sequences available in PhytophthoraID (Grünwald et al., 2011) or the National Center for Biotechnology Information (NCBI, Bethesda, MD) nucleotide database for species identification using Basic Local Alignment Search Tool (BLAST).
MiSeq sequencing data were filtered to remove sequences that were low quality (Phred quality score $<30$ ) and shorter in length $(<100 \mathrm{bp})$. The remaining high-quality, longer sequences were queried against a custom oomycete reference database using a megablast search for species identification (Redekar et al., 2019). The BLAST search allowed for a single best matching ( $>99 \%$ similarity) high scoring query-subject alignment that was at least 150 bp long. The BLAST results were transformed into operational taxonomic units (OTU) and assembled in a table where each OTU corresponded to a unique sequence that was $\geq 99 \%$ similar to known oomycete species.

The samples were grouped by 10 categories such as main source of irrigation water, retention water, runoff water, compost, potting mix, used containers, cull pile, sand and gravel from greenhouses, soil and water under the pots, and plant-associated. Species described within each category comprised at least $1 \%$ of the total population.

The Illumina MiSeq approach based on the ITS1 amplicon cannot distinguish some closely related species. Groups of indistinguishable species were classified as "clusters" or "complexes." Species within a cluster have identical ITSI sequences between the ITS6 and ITS7 priming sites. Species within a complex have ITS1 sequences that are identical along the full length of the ITS1 sequence (Redekar et al., 2019).

\section{Case studies}

Nursery A (Oregon). Nursery $\mathrm{A}$ is a $>500$-acre wholesale container nursery in western Oregon that grows premium woody ornamentals and perennials for retail garden centers. Most nursery beds are sloped to improve drainage and covered with 1 to 2 inches of crushed rock, but some of the older hoop houses are built on less-sloped beds that have become clogged with plant debris and are no longer well drained. The source of irrigation water is a year-round creek, supplemented by well or pond water in summer. All water is filtered and disinfested with sodium hypochlorite or calcium chlorite before use in irrigation. Runoff water is captured in a series of canals, reservoirs, and the 
pond except for occasional overflows that occur during heavy rain events in winter (Fig. 5). The nursery produces its own custom potting media, some of which incorporate compost made at the nursery from culled plant materials. Compost temperatures are monitored throughout the composting process. Incoming plants that are hosts for Phytophthora are tested for the presence of Phytophthora upon arrival.

Plants that were symptomatic of Phytophthora diseases included firs (Abies sp.), false cypress (Chamaecyparis sp.), pine (Pinus sp.), boxwood (Buxus sp.), andromedas (Pieris sp.), and rhododendron (Rhododendron sp.). Symptoms included dampingoff, root rot, crown rot, leaf blight, dieback, and mortality. A list of plant pathogen species detected within the nursery is shown (Table 1). Some root balls were infested with the Phytophthora cryptogea-complex, the Phytophthora citricola-complex, and the Phytophthora citrophthora-complex; Phytophthora lateralis was isolated from false cypress with crown rot. Leaf blight and dieback caused by
Phytophthora plurivora (a member of the $P$. citricola-complex) were found on rhododendron.

The main critical control points in Nursery A were 1) the soil/gravel beds, which serve as a persistent reservoir of inoculum for infesting subsequent crops; 2) certain batches of finished potting media; and 3) used pots where the $P$. cryptogea-complex, the $P$. citricola-complex, and the Phytophthora parsiana-complex were widespread. Although high standards of sanitation were otherwise maintained in the cutting room and propagation house, propagation trays destined for reuse were contaminated with the P. cryptogea-complex and the $P$. citricola-complex; this occurred despite a policy of steaming trays used for propagation. The P. citrophthoracomplex was found in association with false cypress, pine, and rhododendron; and in soil and water under the pots. Several plant pathogenic species (Phytopythium litorale, Pythium dissotocum-complex, and the $P$. cryptogea-complex) were present in the creek and pond water and were enriched in the runoff relative to saprophytic species (Fig. 5). However, the nursery is doing an effective job of disinfesting water before applying it to plants, and so irrigation water is not a critical control point at Nursery A.

The nursery should ensure that potting media and containers, especially those used for propagation, are free of Phytophthora species. If compost is incorporated in potting media, steps should be taken to ensure that temperatures achieved during composting are sufficient to kill pathogens. The compost mix must be turned so that the entire mix reaches the critical temperature, otherwise some compost will escape treatment. Alternatively, media ingredients may be pasteurized $\left[65{ }^{\circ} \mathrm{C}\right.$ for $30 \mathrm{~min}$ (Baker and Cook, 1974)]. In addition, the nursery should consider ways to prevent contact between container plants and infested ground. Nursery beds should be sloped to prevent puddling, and a 3 -inch layer of crushed rock could be added to prevent direct contact between soil and containers. Plant debris should be removed between crops and

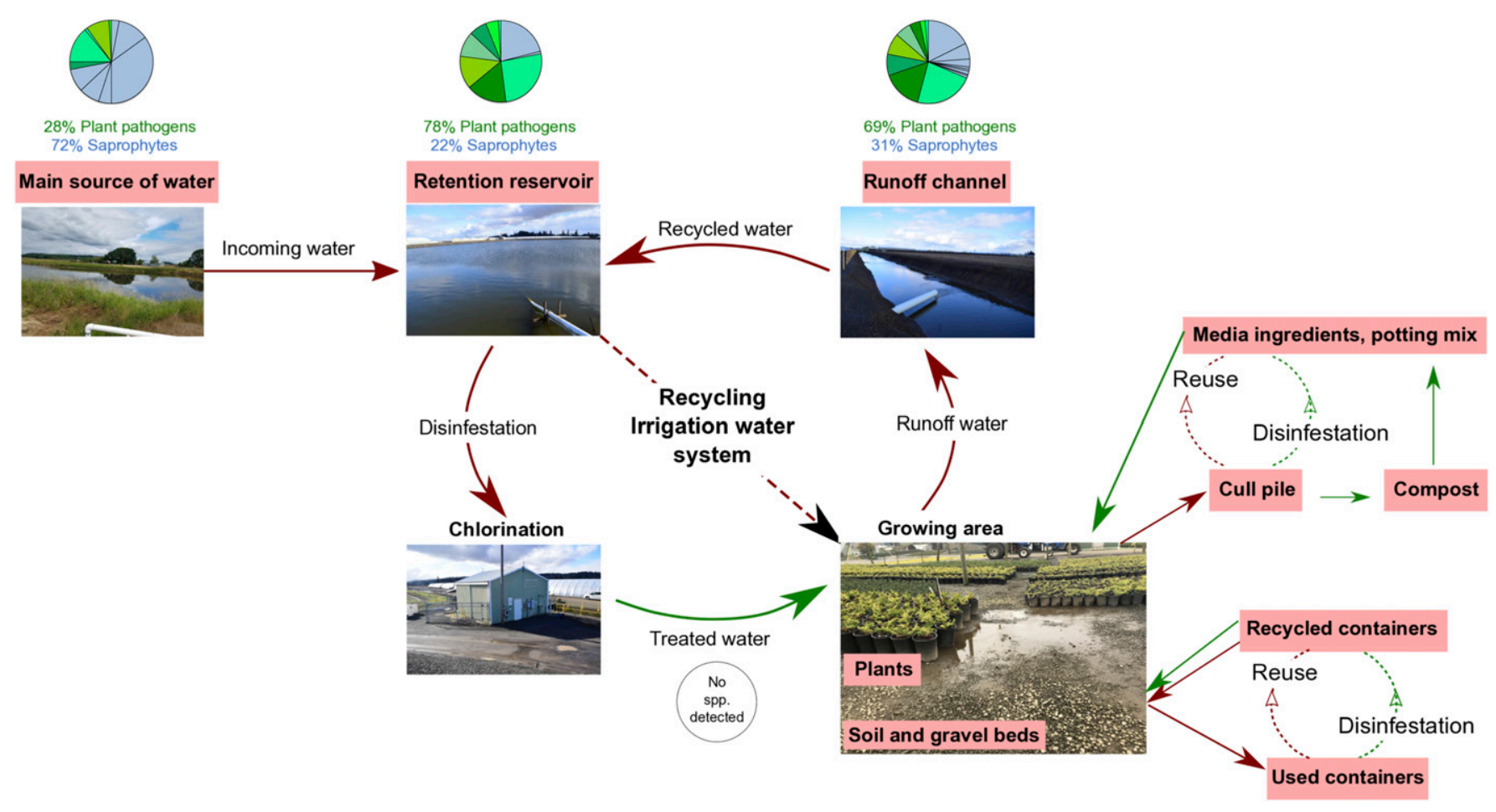

Fig. 5. Diagram of the recycling systems for water, media ingredients, and containers in Nursery A (Oregon). Incoming water from the main source of water is delivered to a retention reservoir. From there it is chlorinated before being applied to plants. Runoff is collected in a runoff channel and pumped back to the retention reservoir. Not all species of waterborne oomycetes are plant pathogens. Some are saprophytes. The pie charts illustrate how the relative abundance of plant pathogenic species (green) was enriched within the nursery compared with the saprophytic species (blue). Used containers are disinfested and reused for plant production. Media ingredients and potting mixes are also recycled by composting or disinfesting culled materials. 
Table 1. Summary of Phytophthora, Phytopythium, and Pythium species detected at critical control points in three nurseries: Nursery A (Oregon), Nursery B (California), and Nursery C (South Carolina).

\begin{tabular}{|c|c|c|c|c|c|c|c|c|c|c|c|}
\hline \multirow{2}{*}{ 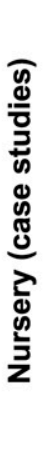 } & \multirow[b]{2}{*}{ Oomycete species ${ }^{2}$} & \multirow[b]{2}{*}{$\begin{array}{c}\text { Pathogenicity } \\
\text { Status }\end{array}$} & \multicolumn{3}{|c|}{$\begin{array}{l}\text { Irrigation } \\
\text { water }\end{array}$} & \multicolumn{4}{|c|}{$\begin{array}{c}\text { Media } \\
\text { ingredients, } \\
\text { containers }\end{array}$} & \multirow{2}{*}{ 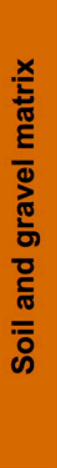 } & \multirow{2}{*}{ 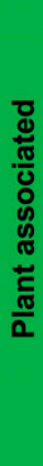 } \\
\hline & & & 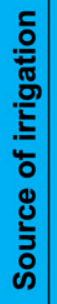 & 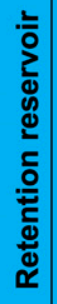 & $\frac{\text { 告 }}{\frac{5}{3}}$ & 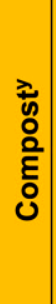 & 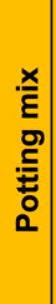 & 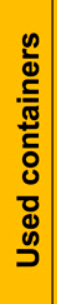 & $\begin{array}{l}\frac{0}{\overline{2}} \\
\overline{\overline{3}} \\
0\end{array}$ & & \\
\hline \multirow{24}{*}{ A } & \multicolumn{11}{|l|}{ Phytophthora } \\
\hline & A novel Phytophthora species & Unknown & & + & + & & + & + & & + & + \\
\hline & P. chlamydospora & Plant pathogen & & & & & & & & + & \\
\hline & P. cinnamomi & Plant pathogen & & & & + & & & & & \\
\hline & P. citricola-complex & Plant pathogen & & + & & & + & + & & + & + \\
\hline & P. citrophthora-complex & Plant pathogen & & & & & & & & + & + \\
\hline & P. cryptogea-complex & Plant pathogen & & + & & + & + & + & & + & + \\
\hline & $P$. lateralis & Plant pathogen & & & & & & & & + & + \\
\hline & $P$. parsiana-complex & Plant pathogen & & & & + & & & & + & + \\
\hline & P. riparia/P. taxon Oaksoil-complex & Saprophyte & + & & & & & & & & \\
\hline & $P$. taxon Oaksoil-complex & Saprophyte & + & & & & & & & & \\
\hline & \multicolumn{11}{|l|}{ Phytopythium } \\
\hline & P. chamaehyphon & Plant pathogen & & & & & & & & + & \\
\hline & P. litorale & Plant pathogen & + & + & + & & & & & + & + \\
\hline & \multicolumn{11}{|l|}{ Pythium } \\
\hline & P. anandrum & Plant pathogen & & & + & & & & & & \\
\hline & $P$. attrantheridium & Unknown & & & & + & & & & & \\
\hline & P. dissotocum-complex & Plant pathogen & & + & + & & & & & + & + \\
\hline & P. flevoense-complex & Fish pathogen & & & + & & & & & & \\
\hline & P. hydnosporum & Plant pathogen & & & & + & & & & + & \\
\hline & P. irregulare-complex & Plant pathogen & & & & & & & & & + \\
\hline & P. sylvaticum-complex & Plant pathogen & & & & + & & & & & \\
\hline & P. ultimum & Plant pathogen & & & & + & & + & & & \\
\hline & Unknown Pythium species & Unknown & & & & + & & & & & \\
\hline \multirow{16}{*}{ B } & \multicolumn{11}{|l|}{ Phytophthora } \\
\hline & A novel Phytophthora species & Unknown & & & + & & + & & & & \\
\hline & P. chlamydospora & Plant pathogen & & & + & & & & & & \\
\hline & P. cinnamomi & Plant pathogen & & & & & + & + & & & + \\
\hline & P. citricola-complex & Plant pathogen & & & + & & + & & & + & + \\
\hline & P. citrophthora-complex & Plant pathogen & & & & & + & + & & & + \\
\hline & P. cryptogea-complex & Plant pathogen & + & + & + & & + & & + & + & + \\
\hline & P. irrigata & $\begin{array}{l}\text { Opportunistic } \\
\text { pathogen }\end{array}$ & & & & & & + & & & \\
\hline & P. nicotianae-complex & Plant pathogen & & & & & & + & & & + \\
\hline & P. palmivora & Plant pathogen & & & & & & & & & + \\
\hline & P. parsiana-complex & Plant pathogen & & + & & & + & + & & & + \\
\hline & P. riparia/P. taxon Oaksoil-complex & Saprophyte & & & + & & & + & & & \\
\hline & P. syringae & Plant pathogen & & & + & & & & & & \\
\hline & P. tropicalis-complex & Plant pathogen & & & & & & & & + & + \\
\hline & Unknown Phytophthora species & Unknown & & & & & & & & & + \\
\hline & \multicolumn{11}{|l|}{ Phytopythium } \\
\hline
\end{tabular}

(Continued on next page)

drainage should be improved in poorly drained areas. The nursery could solarize nursery beds and greenhouses to disinfest the soil/gravel substrate if it is feasible to keep these areas free of plants during a 4-week period during the summer (Funahashi and Parke, 2016). Nursery A tests host plants obtained from off-site for the presence of Phytophthora species; however, plants should be set aside for several weeks and tested before 
Table 1. (Continued) Summary of Phytophthora, Phytopythium, and Pythium species detected at critical control points in three nurseries: Nursery A (Oregon), Nursery B (California), and Nursery C (South Carolina).

\begin{tabular}{|c|c|c|c|c|c|c|c|c|c|c|}
\hline & P. helicoides & Plant pathogen & & & & & & & + & + \\
\hline & P. litorale & Plant pathogen & & & + & & & & + & + \\
\hline & \multicolumn{10}{|l|}{ Pythium } \\
\hline & P. attrantheridium & Unknown & & & & + & & & & + \\
\hline & P. chondricola & $\begin{array}{c}\text { Algae } \\
\text { pathogen }\end{array}$ & & & + & & & & & \\
\hline & P. dissotocum-complex & Plant pathogen & & + & + & & & & + & + \\
\hline & P. flevoense-complex & Plant pathogen & + & + & + & & & & & \\
\hline & P. hydnosporum & Plant pathogen & & + & & + & + & & & + \\
\hline & $P$. irregulare-complex & Plant pathogen & & & & & + & & & + \\
\hline & P. kashmirense & Plant pathogen & & & & & & & + & \\
\hline & P. macrosporum & Plant pathogen & & & & & + & & & \\
\hline & P. pachycaule & Plant pathogen & & & + & & & & & \\
\hline & P. rhizo-oryzae-complex & Plant pathogen & & + & + & & & & + & \\
\hline & P. sylvaticum-complex & Plant pathogen & & & & & & & & + \\
\hline & P. ultimum & Plant pathogen & & & & + & & & & \\
\hline & Unknown Pythium species & Unknown & & & + & & & & + & + \\
\hline \multirow{16}{*}{ C } & \multicolumn{10}{|l|}{ Phytophthora } \\
\hline & P. cactorum & Plant pathogen & & & & & & & & + \\
\hline & P. chlamydospora & Plant pathogen & & & & & & & & + \\
\hline & P. cinnamomi & Plant pathogen & & & & & & & & + \\
\hline & P. citricola-complex & Plant pathogen & & & & & & & & + \\
\hline & P. hydrogena & Saprophyte & & + & & & & & & \\
\hline & P. irrigata & $\begin{array}{l}\text { Opportunistic } \\
\text { pathogen }\end{array}$ & & + & + & & & & & + \\
\hline & $P$. lateralis & Plant pathogen & & & & & & & & + \\
\hline & P. nicotianae-complex & Plant pathogen & & & & & & & & + \\
\hline & $P$. parsiana-complex & Plant pathogen & & + & + & & & & + & + \\
\hline & \multicolumn{10}{|l|}{ Phytopythium } \\
\hline & P. helicoides & Plant pathogen & + & + & & & & + & & + \\
\hline & $P$. litorale & Plant pathogen & & & & & & & + & \\
\hline & P. vexan-complex & Unknown & & & & + & & & & \\
\hline & \multicolumn{10}{|l|}{ Pythium } \\
\hline & $P$. irregulare-complex & Plant pathogen & & & & & & & & + \\
\hline
\end{tabular}

${ }^{z}$ Detections were based on sequencing of the DNA extracted from baits, cultures, and filters with either Sanger sequencing or high-throughput methods. ${ }^{y}$ Compost was not available to test in Nurseries B and C.

blending plants with existing stock. Methods for testing plant material for Phytophthora species are demonstrated in two online videos (Redekar et al., 2018a, 2018b). Nondestructive methods for testing intact root balls for Phytophthora are available (Vercauteren et al., 2013). Quarantined plants should not be treated with oomycete-specific fungicides so that plants that are potentially infected may express symptoms. To reduce sporulation during the monitoring period, quarantined plants can be sprayed with film-forming polymers or surfactants (Peterson et al., 2019).

Nursery B (California). Nursery $\mathrm{B}$ is a large, 450 -acre nursery in southern California that produces plants for distribution through retail garden centers and national chain stores. Water conservation is a major concern at this nursery, which draws from a reservoir fed by the Colorado
River. Runoff water is collected in settling ponds and then pumped through a rapid sand filter to a retention basin for recycling and treatment with chlorine dioxide. Plant stock includes a wide variety of herbaceous and woody plants grown in containers either outdoors, in greenhouses, or under shade. The nursery accepts unsold plant material, especially roses (Rosa sp.) grown in 2 - to 5 -gal containers, from national chain stores at the end of the summer, and prunes, fertilizes, and grows this material until the next growing season.

Plants infested with Phytophthora species included bougainvillea (Bougainvillea sp.), 'Star of Madeira' echium (Echium fastuosum), gardenia (Gardenia veitchii), 'Heavenly Cloud' sage (Leucophyllum frutescens), mexican cardinal flower (Lobelia laxiflora), red yucca (Hesperaloe parviflora), hydrangea (Hydrangea macrophylla), crape myrtle (Lagerstroemia indica), fragrant olive (Osmanthus fragrans), new zealand flax (Phormium tenax), stone pine (Pinus pinea), rose, and rosemary (Rosmarinus officinalis). Symptoms included chlorosis, root rot, wilting, dieback, and leaf blight. A wide diversity of oomycete species was associated with plants including the Phytophthora cryptogea-complex, the Phytophthora nicotianae-complex, the Phytophthora tropicalis-complex, Phytophthora palmivora, Phytophthora cinnamomi, Pythium dissotocumcomplex, and Phytopythium helicoides. $P$. helicoides causes root rot on a wide variety of greenhouse-grown crops (Beaulieu et al., 2017; Kageyama et al., 2002; Yang et al., 2013), stem and root rot of field-grown trees (Chen et al., 2016; Fichtner et al., 2016) and could be causing subclinical levels of disease in nursery-grown 
container plants. The P. tropicaliscomplex was only found in the soil matrix in greenhouses, and no source of $P$. palmivora was detected in the nursery other than on infested plants, suggesting that it was introduced into the nursery on infested plants (Table 1, Fig. 2).

Critical control points in this nursery were the cull pile, which was infested with the $P$. cryptogeacomplex, and potting media made with ground material from the cull pile. Recycled containers were also infested with the $P$. nicotianaecomplex. Phytophthora species were detected in the soil/gravel beds under containers, and in mud on top of the weed cloth. The reservoir water is infested with high levels of Pythium flevoense, a fish pathogen, and low levels of two plant pathogens, Phytophthora cryptogea-complex and $P$. litorale. This untreated reservoir water is often blended with recycled runoff water that has been disinfested with chlorine dioxide before reuse. Runoff water is enriched with the $P$. citricola-complex, the $P$. dissotocumcomplex, and P. litorale. Evidence for plant pathogenicity of $P$. litorale is mixed. Phytopythium litorale is commonly isolated from irrigation ponds in Georgia where it was shown to cause seedling damping-off and fruit rot of squash (Cucurbita pepo) (Parkunan and Ji, 2013), but isolates from greenhouse water tanks in Pennsylvania were not pathogenic in assays with geranium (Pelargonium $\times$ hortorum) seedlings (Choudhary et al., 2016). It is not known if $P$. litorale is causing disease in Nursery B.

Changes to nursery management practices should include preventing contamination of potting media from the cull pile. The cull pile should be properly managed to eliminate plant pathogens by composting or pasteurization, or it should not be included in potting media. Recycled containers should be steamed before reuse. Plant debris and potting media residues should not be allowed to accumulate on greenhouse benches, weed cloth, or gravel nursery beds. The nursery also puts itself at risk by allowing returns of unsold plant material. The large container plants may harbor several pests and diseases from their exposure in retail centers; allowing returns to the nursery could introduce these pests and diseases to their on-site planting stock. Finally, water from the reservoir should be disinfested before blending with treated recycled water.

Nursery C (South Carolina). Nursery $\mathrm{C}$ is a $<100$-acre facility in the coastal lowlands of South Carolina. Specializing in container-grown perennials, shrubs, and trees, Nursery $\mathrm{C}$ distributes their planting material to landscaping professionals and retail garden centers throughout the midAtlantic and southeastern states. Irrigation water is sourced from a series of linked retention ponds that receive runoff from the nursery and some surface water and groundwater from an adjacent canal during high flow events. Irrigation water is filtered but otherwise untreated except for chlorination of water used in the propagation greenhouses.

Symptomatic plants infested with Phytophthora and related genera included boxwood (Buxus richardii), japanese plum yew (Cephalotaxus harringtonia), holly (Ilex sp.), 'Soft Caress' mahonia (Mahonia eurybracteata), fragrant olive (Osmanthus fragrans), indian hawthorne (Raphiolepis indica), and rhododendron. In contrast to Nurseries A and B, few plant-associated Phytophthora species were found in Nursery C, which is smaller and has less diversity of plant material than the other two nurseries. The most widespread plant pathogens in Nursery C were Phytopythium helicoides, found in association with plants and also in irrigation water, and the Phytophthora parsiana-complex. Other plant-associated species included the Phytophthora nicotianaecomplex, Phytophthora cinnamomi, Phytophthora cactorum, and the $P$. citricola-complex. Phytophthora lateralis was found in association with 'Soft Caress' mahonia, a surprising finding because $P$. lateralis' host range is known to include only false cypress and yew (Taxus sp.). It is possible that $P$. lateralis was recently brought into the nursery "hitchhiking" in infested potting media or pots. P. lateralis is well adapted to survival in soil and dispersal in water in cooler climates but does not appear to have established in the nursery, perhaps because the warm summer temperatures are not favorable to its growth.

The main critical control point in Nursery $\mathrm{C}$ is irrigation water that harbors $P$. helicoides. All water used for irrigation should be disinfested before application. Several methods for water disinfestation are available (Majsztrik et al., 2017). In addition, any plants acquired from off site should be grown in isolation for several weeks and tested for Phytophthora species as described previously to reduce the risk of introducing these pathogens into the nursery.

\section{Discussion}

Hazard analysis at the three nurseries revealed that the main source of irrigation water for each nursery is infested with species of Phytophthora, Phytopythium, and Pythium. Many of these species are known plant pathogens, although some species are saprophytic or aquatic opportunists (Hansen et al., 2012). Our findings are consistent with other studies indicating that surface sources of water (rivers, streams, ponds) are commonly infested with Phytophthora species (Copes et al., 2015; Hansen et al., 2012; Hong and Moorman, 2005; Hong et al., 2009, 2012; Loyd et al., 2014; Olson et al., 2013; Parke et al., 2014; Redekar et al., 2019; Sims et al., 2015). All three nurseries recaptured runoff water; this practice conserves water but appears to enrich for plant pathogenic species as shown with Nursery A and B, underscoring the importance of disinfesting recycled water.

While our hazard analysis targeted critical control points for Phytophthora contamination, it should be noted that other water molds (Phytopythium, Pythium) were also detected with our baiting and sequencing methods. For those specifically interested in detecting Pythium species, improved methods, such as dilution plating onto hymexazol-free media and possibly baiting with a plant leaf different from rhododendron, should be considered (Alcala et al., 2016; Weiland et al., 2015). Unfortunately, there are no commercial diagnostic kits for detecting Pythium species on baits, so growers would need to submit water or plant samples to a plant disease diagnostic clinic to confirm the presence of Pythium species.

Our hazard analysis is modeled after HACCP, but we did not attempt to establish critical limits for each critical control point. For example, 
we only tested for the presence of Phytophthora rather than establishing a threshold for damaging levels of Phytophthora in water. The relationship between inoculum dose and disease response is still poorly understood. Foliar infection of nursery plants from irrigation water infested with Phytophthora has been demonstrated but mainly with 'acute' inoculum levels, much higher that is typically found in nursery irrigation systems (Benson and Jones, 1980; Tjosvold et al., 2008; Werres et al., 2007). In one study (Loyd et al., 2014), little disease developed in plants that were exposed to 'chronic' low levels of Phytophthora inoculum applied in infested irrigation water over several months. The disease risk likely differs among Phytophthora species, hosts, and environmental conditions, so a prudent management approach is to disinfest irrigation water if any Phytophthora is detected. There are many options for water treatment (Majsztrik et al., 2017; Raudales et al., 2014; Zheng, 2018). Growers can test the effectiveness of their water treatment by baiting and use a diagnostic kit to determine if Phytophthora is present on the baits. Critical limits have been developed for steaming (Schweigkofler et al., 2014) or pasteurization of soil and media ingredients and of containers (Baker, 1957; Linderman and Davis, 2008).

It is unlikely that a hazard analysis such as ours detected all sources of contamination. It is impossible to sample every plant, container, or batch of potting media. Nurseries are inherently dynamic production systems; the plants themselves are constantly moved around the nursery, and new plants are coming in as others are sold. There are a limited number of samples that can be processed in a timely way, and the choice of selective media and the time of year sampled influence the outcome. In a 4-year study in Oregon nurseries (Parke et al., 2014), we determined that fall was the best time of year to recover the greatest diversity of Phytopththora species, but the optimal sampling period has not, to our knowledge, been determined for southern California or South Carolina, where the seasonal pattern of temperature and rainfall are different. Although we avoided time periods with extremely hot or cold temperatures, it is possible that we sampled Nurseries B and C at times of the year that were suboptimal. Moreover, any single type of bait is unlikely to capture all species of Phytophthora. By employing both DNA-based and culture-based approaches, we were able to overcome some of the inherent biases in baiting or plating, and we improved our capacity to detect Phytophthora species that occur in mixed populations. Though incomplete, hazard analysis provides a 'snapshot' of contamination sources at the time of sampling.

Once critical control points within the nursery are identified, management practices can be implemented to reduce the risk of economic loss and disease spread. Resources are available to help growers assess contamination hazards in their nurseries (Griesbach et al., 2012), and an online decision tool will soon be available on the Clean WateR ${ }^{3}$ website (Parke et al., 2018; University of Florida, 2019). Growers will be able to answer a few questions about their growing facility and then receive a disease risk score to help them prioritize changes they can make to reduce their risk. Although we have focused on Phytophthora species, many of the recommended best management practices should be effective in reducing other waterborne and soilborne pests and diseases in the nursery. For example, growers that steam their used containers to eliminate Phytophthora contamination report greatly reduced levels of weed seed germination. The reduced labor costs more than paid for the steam treatment (J.L. Parke, unpublished data).

The long-term goal of the Clean Wate $\mathrm{R}^{3}$ program is to encourage recycling of runoff water. The three case studies illustrate the need to disinfest recycled runoff water to prevent waterborne dissemination of Phytophthora, Pythium, and Phytopythium species. Although growers should implement a system for effective water treatment, this is best accomplished as part of an overall hazard analysis to identify and then eliminate critical control points of Phytophthora contamination. Targeted changes to nursery management practices will reduce the risk of disease and help protect the health of landscapes and wildlands.

\section{Literature cited}

Alcala, A.V.C., T.C. Paulitz, K.L. Schroeder, L.D. Porter, M.L. Derie, and L.J. Du Toit. 2016. Pythium species associated with damping-off of pea in certified organic fields in the Columbia Basin of central Washington. Plant Dis. 100: 916-925.

Baker, K.F. 1957. The U. C. system for producing healthy container-grown plants: Through the use of clean soil, clean stock, and sanitation. Univ. California, Agr. Expt. Sta., Ext. Serv., Berkeley.

Baker, K.F. and R.J. Cook. 1974. Biological control of plant pathogens. Freeman, San Francisco, CA.

Beaulieu, J., B. Ford, and Y. Balci. 2017. Genotypic diversity of Phytophthora cinnamomi and $P$. plurivora in Maryland's nurseries and mid-Atlantic forests. Phytopathology 107:769-776.

Benson, D.M. and R.K. Jones. 1980. Etiology of rhododendron dieback caused by four species of Phytophthora. Plant Dis. 64:687-691.

Burke, D.J., A.M. Kretzer, P.T. Rygiewicz, and M.A. Topa. 2006. Soil bacterial diversity in a loblolly pine plantation: Influence of ectomycorrhizas and fertilization. FEMS Microbiol. Ecol. 57:409-419.

Chen, X.-R., B.-B. Liu, Y.-P. Xing, B.-P. Cheng, M.-L. Liu, Y.-H. Tong, and J.-Y. $\mathrm{Xu} .2016$. Identification and characterization of Phytopythium helicoides causing stem rot of Shatangju mandarin seedlings in China. Eur. J. Plant Pathol. 146:715-727.

Choudhary, C.E., M.L. Burgos-Garay, G.W. Moorman, and C. Hong. 2016. Pythium and Phytopythium species in two Pennsylvania greenhouse irrigation water tanks. Plant Dis. 100:926-932.

Cobb, R. 2018. California Oak Mortality Task Force (COMTF) November 2018 report. 25 Feb. 2019. <http://www. suddenoakdeath.org/wp-content/ uploads/2018/11/COMTF-ReportNov-2018.pdf>

Copes, W.E., X. Yang, and C. Hong. 2015. Phytophthora species recovered from irrigation reservoirs in Mississippi and Alabama nurseries and pathogenicity of three new species. Plant Dis. 99:13901395.

Fichtner, E.J., G.T. Browne, M. Mortaz, L. Ferguson, and C.L. Blomquist. 2016. First report of root rot caused by Phytopythium helicoides on pistachio rootstock in California. Plant Dis. 100:2337.

Funahashi, F. and J.L. Parke. 2016. Effects of soil solarization and Trichoderma asperellum on soilborne inoculum of 
Phytophthora ramorum and Phytophthora pini in container nurseries. Plant Dis. 100:438-443.

Garbelotto, M., S. Frankel, and B. Scanu. 2018. Soil- and waterborne Phytophthora species linked to recent outbreaks in northern California restoration sites. Calif. Agr. 72(4):208-216.

Goss, E.M., M. Larsen, G.A. Chastagner, D.R. Givens, and N.J. Grünwald. 2009. Population genetic analysis infers migration pathways of Phytophthora ramorum in US nurseries. PLoS Pathog. 5:e1000583.

Griesbach, J., J. Parke, G. Chastagner, N. Grünwald, and J. Aguirre. 2012. Safe procurement and production manual. 19 Feb. 2019. <https://www.oan.org/ page $/ 861$ ? \&h h searchterms $=\%$ 22 safe+and+procurement $\% 22>$.

Grünwald, N.K., F.N. Martin, M. Larsen, C. Sullivan, C.M. Press, M.D. Coffey, E.M. Hansen, and J.L. Parke. 2011. Phytophthora-ID.org: A sequence based Phytophthora identification tool. Plant Dis. 95:337-342.

Hansen, E.M., D.J. Goheen, E.S. Jules, and B. Ullian. 2000. Managing portorford-cedar and the introduced pathogen Phytophthora lateralis. Plant Dis. 84: 4-14.

Hansen, E.M., P.W. Reeser, and W. Sutton. 2012. Phytophthora beyond agriculture. Annu. Rev. Phytopathol. 50: 359-378.

Hong, C., J.D. Lea-Cox, D.S. Ross, G.W. Moorman, P.A. Richardson, S.R. Ghimire, and P. Kong. 2009. Containment basin water quality fluctuation and implications for crop health management. Irr. Sci. 27: 485-496.

Hong, C.X. and G.W. Moorman. 2005. Plant pathogens in irrigation water: Challenges and opportunities. Crit. Rev. Plant Sci. 24:189-208.

Hong, C., P.A. Richardson, W. Hao, S.R. Ghimire, P. Kong, G.W. Moorman, J.D. Lea-Cox, and D.S. Ross. 2012. Phytophthora aquimorbida sp. nov. and Phytophthora taxon 'Aquatilis' recovered from irrigation reservoirs and a stream in Virginia, USA. Mycologia 104:10971108.

Ivors, K.L. and G.W. Moorman. 2017. Oomycete plant pathogens in irrigation water, p. 57-64. In: C. Hong, G.W. Moorman, W. Wohanka, and C. Büttner (eds.). Biology, detection, and management of plant pathogens in irrigation water. APS Press, St. Paul, MN.

Jones, R.K. and D.M. Benson. 2001. Diseases of woody ornamentals and trees in nurseries. APS Press, St. Paul, MN.
Jung, T., A. Perez-Sierra, A. Duran, M. Horta Jung, Y. Balci, and B. Scanu. 2018. Canker and decline diseases caused by soil- and airborne Phytophthora species in forests and woodlands. Persoonia 40:182220.

Junker, C., P. Goff, S. Wagner, and S. Werres. 2016. Occurrence of Phytophthora species in commercial nursery production. Plant Health Prog. 17:64-75.

Kageyama, K., T. Aoyagi, R. Sunouchi, and H. Fukui. 2002. Root rot of miniature roses caused by Pythium helicoides. J. Gen. Plant Pathol. 68:15-20.

Liebhold, A.M., E.G. Brockerhoff, L.J. Garrett, J.L. Parke, and K.O. Britton. 2012. Live plant imports: The major pathway for forest insect and pathogen invasions of the US. Front. Ecol. Environ. 10:135-143.

Linderman, R.G. and E.A. Davis. 2008. Eradication of Phytophthora ramorum and other pathogens from potting medium or soil by treatment with aerated steam or fumigation with metam sodium. HortTechnology 18:106-110.

Loyd, A.L., D.M. Benson, and K.L. Ivors. 2014. Phytophthora populations in nursery irrigation water in relationship to pathogenicity and infection frequency of Rhododendron and Pieris. Plant Dis. 98:1213-1220.

Majsztrik, J.C., R.T. Fernandez, P.R. Fisher, D.R. Hitchcock, J. Lea-Cox, J.S. Owen, Jr., L.R. Oki, and S.A. White. 2017. Water use and treatment in container-grown specialty crop production: A review. Water Air Soil Pollut. 228:151, doi: 10.1007/s11270-017-3272-1.

Ockels, F.S., M.V. Dileo, and P. Bonello. 2007. Desiccation at ambient temperature effectively preserves plant tissues infected with Phytophthoras. Plant Health Prog., doi: 10.1094/PHP-20070302-01-RS.

Olson, H.A., S.N. Jeffers, K.L. Ivors, K.C. Steddom, J.L. Williams-Woodward, M.T Mmbaga, D.M. Benson, and C.X. Hong. 2013. Diversity and mefenoxam sensitivity of Phytophthora spp. associated with the ornamental horticulture industry in the southeastern United States. Plant Dis. 97:86-92.

Parke, J., C. Swett, and J. Majsztrik. 2018. Tools for growers to assess disease risk. HortScience 53(9S):70 (Abstr.).

Parke, J.L. and N.J. Grünwald. 2012. A systems approach for management of pests and pathogens of nursery crops. Plant Dis. 96:1236-1244.

Parke, J.L., B.J. Knaus, V.J. Fieland, C. Lewis, and N.J. Grunwald. 2014. Phy- tophthora community structure analyses in Oregon nurseries inform systems approaches to disease management. Phytopathology 104:1052-1062.

Parke, J.L. and C. Lewis. 2007. Root and stem infection of rhododendron from potting medium infested with Phytophthora ramorum. Plant Dis. 91:12651270.

Parkunan, V. and P. Ji. 2013. Isolation of Pythium litorale from irrigation ponds used for vegetable production and its pathogenicity on squash. Can. J. Plant Pathol. 35:415-423.

Peterson, E.K., E. Larson, and J.L. Parke. 2019. Film-forming polymers and surfactants reduce infection and sporulation of Phytophthora ramorum on rhododendron. Plant Dis. 103:1148-1155. <https:// apsjournals.apsnet.org/doi/abs/10. 1094/PDIS-05-18-0802-RE>.

Raudales, R.E., J.L. Parke, C.L. Guy, and P.R. Fisher. 2014. Control of waterborne microbes in irrigation: A review. Agr. Water Mgt. 143:9-28.

Redekar, N.R., J.L. Eberhart, and J.L. Parke. 2019. Diversity of Phytophthora, Pythium, and Phytopythium species in recycled irrigation water in a container nursery. Phytobiomes J. 10 Apr. 2019. <https://apsjournals.apsnet.org/doi/ abs/10.1094/PBIOMES-10-18-0043$\mathrm{R}>$.

Redekar, N.R., J.L. Parke, and J. Eberhart. 2018a. Baiting: A method for early detection of Phytophthora. 28 Jan. 2019. <http://www.youtube.com/watch? reload $=9 \& v=S J \times 7 g z X y X o M>$.

Redekar, N.R., J.L. Parke, and J. Eberhart. 2018b. How to use rapid test kits to detect Phytophthora in plant samples. 28 Jan. 2019. <http://www. youtube.com $/$ watch? $\mathrm{v}=5 \mathrm{Boqfl} I \mathrm{Nwg}>$.

Rooney-Latham, S., C.L. Blomquist, T. Swiecki, E. Bernhardt, and S.J. Frankel. 2015. First detection in the US: New plant pathogen, Phytophthora tentaculata, in native plant nurseries and restoration sites in California. Native Plants J. 16:23-27.

Schweigkofler, W., K. Kosta, V. Huffman, S. Sharma, K. Suslow, and S. Ghosh. 2014. Steaming inactivates Phytophthora ramorum, causal agent of sudden oak death and ramorum blight, from infested nursery soils in California. Plant Health Prog. 15:43-47.

Sims, L.L. and M. Garbelotto. 2018. Susceptibility to the rare Phytophthora tentaculata and to the widespread Phytophthora cactorum is consistent with host ecology and history. For. Pathol. 48:12446 doi: $10.1111 /$ efp.12446. 
Sims, L.L., W. Sutton, P. Reeser, and E.M. Hansen. 2015. The Phytophthora species assemblage and diversity in riparian alder ecosystems of western Oregon, USA. Mycologia 107:889-902.

Swiecki, T.J., M. Quinn, L. Sims, E. Bernhardt, L. Oliver, T. Popenuck, and M.M. Garbelotto. 2018. Three new Phytophthora detection methods, including training dogs to sniff out the pathogen, prove reliable. Calif. Agr. 72(4):217-225.

Tjosvold, S.A., D.L. Chambers, S.T. Koike, and S.R. Mori. 2008. Disease on nursery stock as affected by environmental factors and seasonal inoculum levels of Phytophthora ramorum in stream water used for irrigation. Plant Dis. 92:15661573.

University of Florida. 2019. Clean Wate $\mathrm{R}^{3}$-Reduce, remediate, recycle. 10 Apr. 2019. Lhttps://www. cleanwater3.org $>$.
U.S. Department of Agriculture. 2009. Pest management strategic plan for container and field-produced nursery crops. 25 Feb. 2019. <https://ipmdata. ipmcenters.org/documents/pmsps/GAKY-NC-SC-TNnurserycropsPMSP.pdf $>$.

Vercauteren, A., M. Riedel, M. Maes, S. Werres, and K. Heungens. 2013. Survival of Phytophthora ramorum in rhododendron root balls and in rootless substrates. Plant Pathol. 62:166-176.

Weiland, J.E., P. Garrido, Z.N. Kamvar, A.S. Espindola, S.M. Marek, N.J. Grunwald, and C.D. Garzon. 2015. Population structure of Pythium irregulare, P. ultimum, and P. sylvaticum in forest nursery soils of Oregon and Washington. Phytopathology 105:684-694.

Werres, S., S. Wagner, T. Brand, K Kaminski, and D. Seipp. 2007. Survival of Phytophthora ramorum in recirculating irrigation water and subsequent infection of Rhododendron and Viburnum. Plant Dis. 91:1034-1044.

White, T.J., T. Bruns, S. Lee, and J.L. Taylor. 1990. Amplification and direct sequencing of fungal ribosomal RNA genes for phylogenetics, p. 315-322. In: PCR protocols: A guide to methods and applications. Academic Press, San Diego, CA.

Yang, X., W. Copes, and C. Hong. 2013. Phytophthora mississippiae sp. nov., a new species recovered from irrigation reservoirs at a plant nursery in Mississippi. J. Plant Pathol. Microbiol. 4:180.

Zheng, Y. 2018. Greenhouse and nursery water treatment information system. 28 Jan. 2019. <http://www.ces.uoguelph. $\mathrm{ca} /$ water/pathogen.shtml>. 